https://doi.org/10.15407/ujpe63.6.538

C.O. AREÁN

Department of Chemistry, University of the Balearic Islands

(Palma, Spain)

\title{
PROBING BRØNSTED \\ ACIDITY OF PROTONIC ZEOLITES WITH VARIABLE-TEMPERATURE INFRARED SPECTROSCOPY
}

\begin{abstract}
Most industrial applications of zeolites as solid-acid catalysts rely on their high Brønsted acidity, which affects both catalytic activity and selectivity, and hence the convenience to find an accurate experimental technique for measuring the acid strength. The enthalpy change, $\Delta H^{0}$, involved in the hydrogen bonding interaction between a weak base (such as carbon monoxide) and the Brønsted acid [Si(OH)Al] hydroxyl groups should correlate directly with the zeolite acid strength. However, on account of simplicity, the bathochromic shift of the $\mathrm{O}-\mathrm{H}$ stretching frequency, $\Delta \nu(\mathrm{OH})$, is usually measured by IR spectroscopy at a (fixed) low temperature instead of $\Delta H^{0}$ and correlated with the acid strength for ranking the zeolite acidity. Herein, the use of variable-temperature IR spectroscopy to determine simultaneously $\Delta H^{0}$ and $\Delta \nu(O H)$ is demonstrated, followed by a review of recent experimental results showing that the practice of ranking the acid strength by the corresponding $O-H$ frequency shift probed by a weak base could be misleading; and that can be so much the case of zeolites showing a wide range of structure types.

Ke ywords: Brønsted acidity, infrared spectroscopy, zeolites.
\end{abstract}

\section{Introduction}

Zeolites are three-dimensional aluminosilicates composed of corner sharing tetrahedral $\mathrm{SiO}_{4}$ and $\mathrm{AlO}_{4}$ units that form a crystalline framework characteristic of each zeolite structure type, which encloses void channels and cavities having entrances of about 3 to $8 \AA$ in diameter [1]. The replacement of $\mathrm{Al}$ for $\mathrm{Si}$ in the tetrahedral units generates a net negative charge that has to be balanced by extraframework (exchangeable) cations or protons, as shown in Scheme 1; in the latter case, protonic zeolites, which show a distinctive Brønsted acidity, are generated. This acidity endows protonic zeolites with widespread applications (as solid acid catalysts) in a large range of chemical processes, which span the petrochemical industry, oil refining, methanol to olefin (MTO) conversion, and the production of fine chemicals, to name only a few examples [2-8]. The strength of their catalytic $[\mathrm{Si}(\mathrm{OH}) \mathrm{Al}]$ hydroxyl groups constitutes a main factor determining the catalytic activity and the se-

(C) C.O. AREÁN, 2018 lectivity of protonic zeolites; and, hence, the importance of having a reliable method to quantify relative acidity. For that purpose, several instrumental techniques can (in principle) be used; among them, solidstate NMR spectroscopy, calorimetry of an adsorbed base (such as $\mathrm{NH}_{3}$ or pyridine), and temperature programmed desorption [9-16].

The aforementioned techniques aside, infrared spectroscopy (at liquid nitrogen temperature) of an adsorbed probe molecule (a weak base) is currently the method most commonly used to rank the zeolite acidity, carbon monoxide often being the probe molecule of choice [17-21], although dinitrogen or carbon dioxide could also be used [22-24]. As shown in Scheme 2, CO interacts with the Brønsted-acid hydroxyl group of the zeolite forming a hydrogenbonded $\mathrm{OH}$... CO complex, which gives rise to a large low-frequency shift, $\Delta \nu(\mathrm{OH})$, of the $\mathrm{O}-\mathrm{H}$ stretching mode $[25,26]$ that can easily be monitored by IR spectroscopy, and the corresponding magnitude of $\Delta \nu(\mathrm{OH})$ is often used to rank the Brønsted acidity of zeolites, assuming that such a magnitude is proportional to the corresponding hydrogen-

ISSN 2071-0194. Ukr. J. Phys. 2018. Vol. 63, No. 6 
bond strength. Nevertheless, recent experimental results obtained by means of variable-temperature IR (VTIR) spectroscopy have shown that such an assumption can be misleading; particularly when dealing with zeolites having different structure types $[27,28]$. The current state of knowledge in this field is reviewed below, after a brief introduction to the physical tenets and practical implementation of the VTIR method.

\section{Outline of the Variable-Temperature IR (VTIR) Spectroscopic Method}

The VTIR method, recently developed, is an instrumental technique particularly well suited to gain access to gas-solid physisorption thermodynamics, while simultaneously obtaining the spectroscopic signature of the adsorption complex, provided that either the solid adsorbent or the molecule being adsorbed from the gas phase has an IR-active mode that undergoes a change brought about by the adsorption process. Referring specifically to the adsorption of CO on protonic zeolites (Sch. 2), let Eq. (1) below represent the adsorption equilibrium:

$\mathrm{Z}-\mathrm{OH}_{(s)}+\mathrm{CO}_{(g)} \leftrightarrows \mathrm{Z}-\mathrm{OH} \cdots \mathrm{CO}$

where Z-OH stands for the Brønsted-acid hydroxyl group of the zeolite, and Z-OH … CO is the hydrogenbonded adsorption complex. In this case, the formation of the adsorption complex involves a characteristic change in the stretching frequency of both, the zeolite hydroxyl group and the (adsorbed) CO molecule; and, hence, any of the corresponding IR absorption bands could (in principle) be used to monitor the adsorption process; however, most frequently the band coming from the $\mathrm{O}-\mathrm{H}$ stretching mode of the hydroxyl group is the one chosen for the experimental measurements. The integrated intensity of that IR absorption band should be proportional to the surface coverage, $\vartheta$, according to the Lambert-Beer law. Therefore, it gives information on the activity (in the thermodynamic sense) of both, the adsorbed species and the empty adsorption sites. Simultaneously, the equilibrium pressure, $p$, gives the activity of the gas phase. Hence, by measuring the IR absorbance and equilibrium pressure at any given temperature, the equilibrium constant, $K$, of the adsorption process (at that temperature) can be determined.

Assuming that changes in specific heat are negligible, the variation of $K$ with temperature, $T$, is related

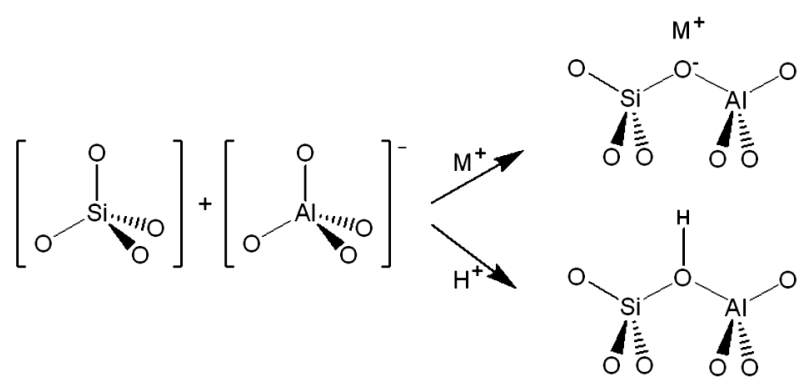

Scheme 1

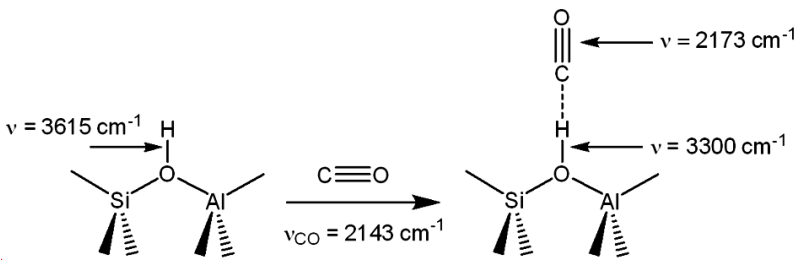

Scheme 2. Wavenumbers are orientative. Actual values depend on the specific zeolite being considered

to the standard adsorption enthalpy, $\Delta H^{0}$, and entropy, $\Delta S^{0}$, through the well-known van't Hoff equation:

$K(T)=\exp \left(-\Delta H^{0} / R T\right) \exp \left(\Delta S^{0} / R\right)$.

For a Langmuir-type adsorption process, combination of Eq. (2) with the Langmuir equation (3) leads to Eq. (4) below:

$\vartheta=K(T) p /[1+K(T) p]$

$\ln \{\vartheta /[(1-\vartheta) p]\}=\left(-\Delta H^{0} / R T\right)+\left(\Delta^{0} / R\right)$.

Alternatively, Eq. (4) can be written as

$\ln \left\{A /\left[\left(A_{M}-A\right) p\right]\right\}=\left(-\Delta H^{0} / R T\right)+\left(\Delta S^{0} / R\right)$,

where $A$ is the actual IR absorbance being measured, and $A_{M}$ stands for the maximum absorbance, which corresponds to $\vartheta=1$. It is clear that, after determining $\vartheta$ (or relative IR absorbance) as a function of $T$ and $p$ over a temperature range, Eq. (4) or (5) provides the direct access to the corresponding values of $\Delta H^{0}$ and $\Delta S^{0}$ which characterize the adsorption equilibrium process. It is worth of note, however, that the assumption made that $\Delta H^{0}$ and $\Delta S^{0}$ are both temperature-independent implies that $\Delta C_{p}^{0}$ (the difference of specific heats at a constant pressure between the gas phase and the adsorbed phase) 
is nil. Strictly speaking, this condition is never fulfilled, because the degrees of freedom of the adsorbate molecule are not the same in both states. However, translational degrees of freedom in the gas phase are replaced by low-lying vibrational modes of the adsorbed molecule [29], which also retains some rotational freedom. Hence, $\Delta C_{p}^{0}$ is expected to be much smaller than $3 R$, and the inclusion of the corresponding correction would not affect significantly the final results. Nevertheless, it should be kept in mind that both $\Delta H^{0}$ and $\Delta S^{0}$ are the values of the thermodynamic quantities actually temperature-dependent and averaged over the temperature range spanned by the VTIR spectroscopic measurement. It is therefore appropriate to refer both of them to the average of that temperature. The further discussion on the potential use and limitations of the VTIR method, including reasons for adopting the Langmuir-type adsorption model, can be found elsewhere [30].

On the experimental side, a properly designed IR cell is needed for recording VTIR spectra. Some commercial cells are adaptable for such a purpose, but most of the experimental results discussed below were obtained by using a homemade IR cell described in detail elsewhere [31]. Measurements are run by dosing a fixed amount of the adsorbate ( $\mathrm{CO}$ ) into the liquid nitrogen cooled cell, which contains a previously activated (outgassed) solid wafer. After that, the cell is closed, and a series of IR spectra is obtained at an increasing temperature, while simultaneously recording the temperature and equilibrium pressure. The cell is thus operated as a closed system in the thermodynamic sense; which is at variance with calorimetric or volumetric gas adsorption measurements usually performed in open systems. Further details on the cell operation and the sample preparation are given in Section 3.1.

\section{Selected Case Studies}

\subsection{Zeolite H-ZSM-5: Structure-type MFI}

A sample of H-ZSM-5, having a nominal Si : Al ratio of $30: 1$, was obtained from a commercial firm and checked by powder X-ray diffraction, which showed a good crystallinity and the absence of any diffraction line not assignable to the corresponding MFI structure type. For VTIR spectroscopy, a thin selfsupported wafer of zeolite was prepared and outgassed by the thermal treatment in a dynamic vacuum (residual pressure smaller than $10^{-4}$ mbar) for
$5 \mathrm{~h}$ at $670 \mathrm{~K}$ inside an IR cell [31] that allowed the in situ sample treatment, gas dosage, and variabletemperature IR spectroscopy to be carried out. After the thermal treatment, the cell was cooled with liquid nitrogen, and 0.2 mbar of helium was admitted into the sample compartment in order to improve the thermal contact between the cell body and the sample wafer. After recording the zeolite blank spectrum, the IR cell was dosed with a fixed amount of CO (just enough to form a 1:1 adsorption complex on every Brønsted-acid hydroxyl group of zeolite) and closed, and a series of IR spectra was recorded upon the gradual warming up of the cell, while simultaneously registering the temperature and gas equilibrium pressure. For that purpose, the cell was equipped with a platinum resistance thermometer (Tinsley) and a capacitance pressure gauge (MKS, Baratron). The precision of these measurements was better than $\pm 10^{-2}$ mbar and $\pm 2 \mathrm{~K}$ for the pressure and temperature, respectively. The pressure correction (for helium) was determined from a previous calibration plot. Transmission FT-IR spectra were recorded at $2 \mathrm{~cm}^{-1}$ resolution on a Bruker IFS66 instrument, accumulating 64 scans for each spectrum. To avoid the repetition, please notice that the same procedure was used for recording the VTIR spectra of the other zeolite samples described below.

As shown in the inset to Fig. 1, the blank spectrum of zeolite displays (in the $\mathrm{O}-\mathrm{H}$ stretching region) the characteristic IR absorption bands at 3746 and $3618 \mathrm{~cm}^{-1}$, which correspond, respectively, to silanols and to the bridged [Si(OH)Al] groups that constitute the zeolite Brønsted-acid sites [17, 19]. Upon the interaction with $\mathrm{CO}$ (in the low pressure range studied herein), the silanol band was not altered, but that at $3618 \mathrm{~cm}^{-1}$ was eroded, and a new (and much broader) band appeared simultaneously at $3315 \mathrm{~cm}^{-1}$, thus testifying to the formation of the corresponding $\mathrm{OH} \cdots \mathrm{CO}$ hydrogen-bonded complex (being $\Delta \nu(\mathrm{OH})=303 \mathrm{~cm}^{-1}$ ).

Figure 1 (main body) displays representative VTIR spectra, which are shown in the difference mode (i.e., after subtracting the blank spectrum of zeolite) in order to avoid any spurious contribution from the background. They show the expected intensity variation of the band at $3618 \mathrm{~cm}^{-1}$ (bridging [ $\left.\mathrm{Si}(\mathrm{OH}) \mathrm{Al}\right] \mathrm{hy}-$ droxyl groups), as the temperature is raised, which parallels that shown by the band at $3315 \mathrm{~cm}^{-1}(\mathrm{O}-\mathrm{H}$ stretching mode of the hydrogen-bonded $\mathrm{OH} \cdots \mathrm{CO}$

ISSN 2071-0194. Ukr. J. Phys. 2018. Vol. 63, No. 6 


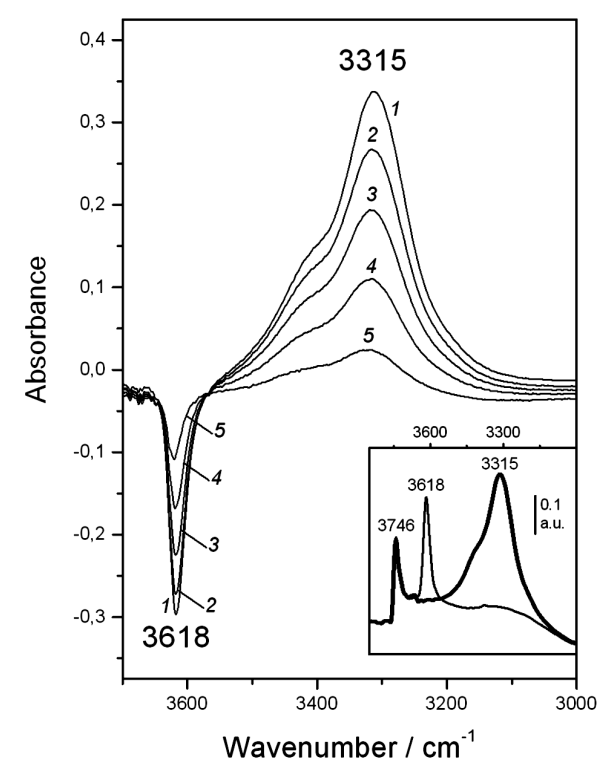

Fig. 1. Representative variable-temperature IR spectra $(\mathrm{O}-\mathrm{H}$ stretching region) of $\mathrm{CO}$ adsorbed on H-ZSM-5. The spectra are shown in the difference mode (zeolite blank subtracted). Temperature (in K) and equilibrium pressure (mbar, in brackets) are as follows: $1-173(4.82) ; 2-190$ (6.23); $3-202$ (6.98); $4-214$ (7.64); $5-230$ (8.39). Inset shows the blank zeolite spectrum and the effect of dosing with $\mathrm{CO}$ at $77 \mathrm{~K}$ (bold line)

complex). From the integrated intensity of the $\mathrm{O}-\mathrm{H}$ stretching band at $3618 \mathrm{~cm}^{-1}$ measured for the whole set of VTIR spectra recorded, the corresponding values for the coverage of adsorption sites, $\vartheta$, were deduced. Note that the intensity of the $\mathrm{O}-\mathrm{H}$ stretching band divided by its maximum value (i.e., that corresponding to the blank zeolite spectrum) gives directly the fraction, $1-\vartheta$, of free $\mathrm{OH}$ sites. From the whole set of $\vartheta, T$ and $p$ values, the plot of Eq. (4) shown in Fig. 2 was obtained. An excellent linear fit can be seen, which led to the values of $\Delta H^{0}=$ $=-29 \mathrm{~kJ} \mathrm{~mol}^{-1}$ (and $\Delta S^{0}=-150 \mathrm{~J} \mathrm{~mol}^{-1} \mathrm{~K}^{-1}$ ) for the standard enthalpy (and entropy) of the formation of the $\mathrm{OH}$... CO hydrogen-bonded complex. The estimated error limits are $\pm 2 \mathrm{~kJ} \mathrm{~mol}^{-1}$ for the enthalpy and $\pm 10 \mathrm{~J} \mathrm{~mol}^{-1} \mathrm{~K}^{-1}$ for the entropy.

\subsection{Protonic ferrierite}

\section{(H-FER): Structure-type FER}

The ferrierite sample was obtained from Zeolyst International, it was in the ammonium form $\left(\mathrm{NH}_{4}-\mathrm{FER}\right)$ and had a $\mathrm{Si}: \mathrm{Al}$ ratio of $27.5: 1$; the conversion into

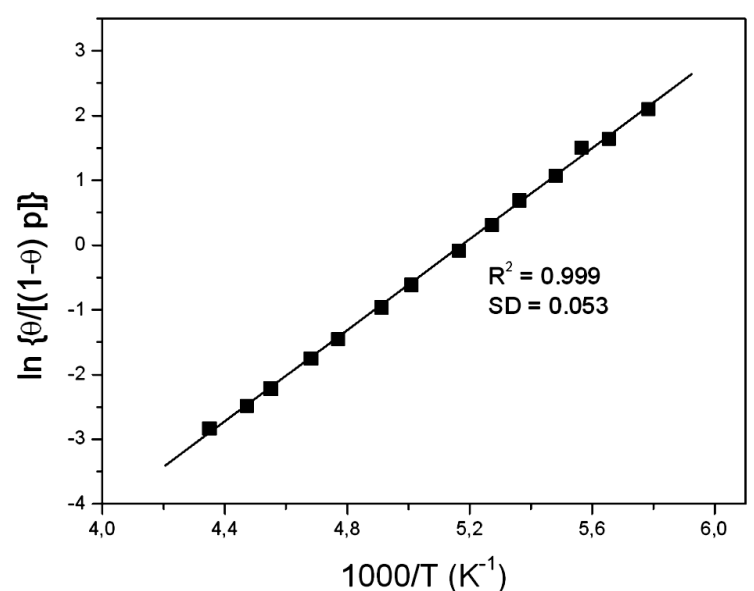

Fig. 2. Plot of the left-hand side of Eq. (4) against the reciprocal temperature for $\mathrm{CO}$ adsorbed on H-ZSM-5; data obtained from the $\mathrm{O}-\mathrm{H}$ stretching band at $3618 \mathrm{~cm}^{-1}$. $\mathrm{R}$, linear regression coefficient; SD, standard deviation

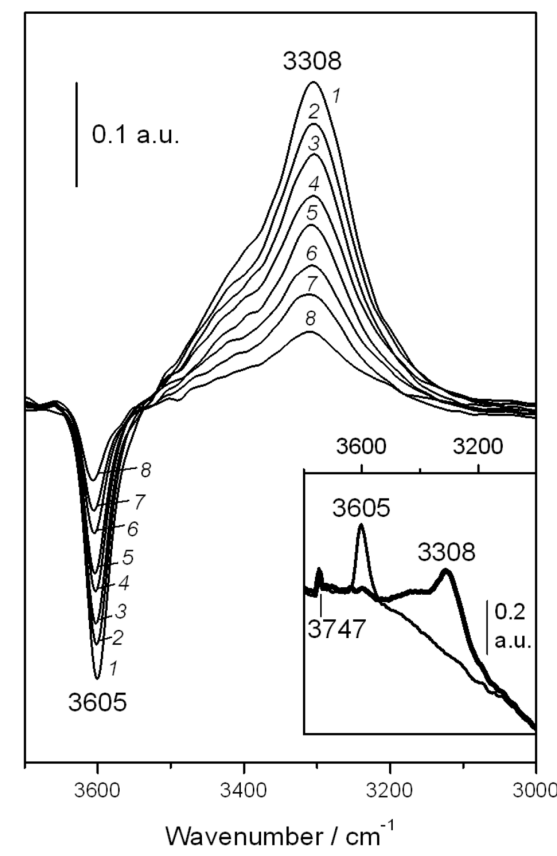

Fig. 3. As in Fig. 1; CO adsorbed on H-FER. Temperature (in $\mathrm{K})$ and equilibrium pressure (mbar, in brackets) are as follows: $1-167$ (0.76); $2-178$ (1.07); $3-133(1.25) ; 4-191$ (1.48); $5-195$ (1.59); $6-202$ (1.80); $7-206$ (1.92); $8-215(2.15)$

the protonic form (H-FER) was achieved and checked, as described elsewhere [32]. The IR spectrum of a blank zeolite wafer (depicted in the inset of Fig. 3) showed the characteristic $\mathrm{O}-\mathrm{H}$ stretching band of the Brønsted-acid hydroxyl groups at $3605 \mathrm{~cm}^{-1}$ together 


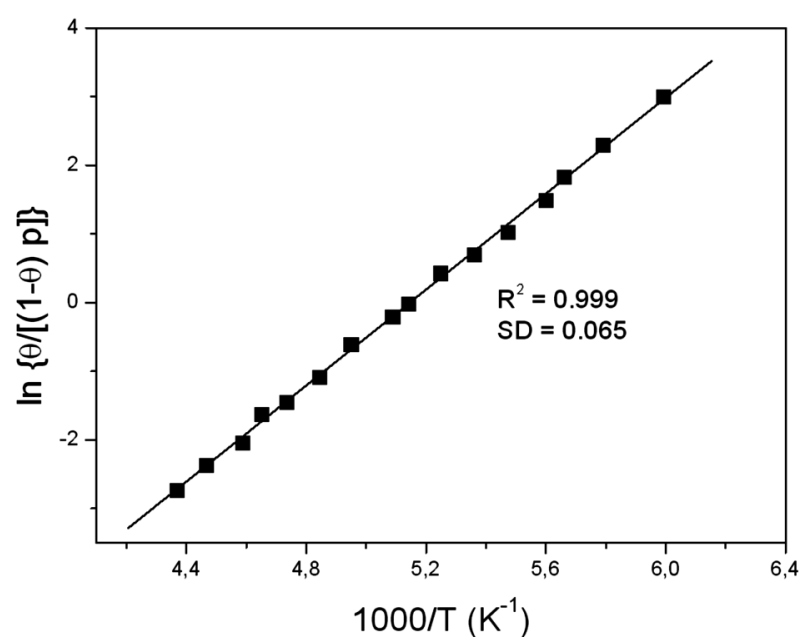

Fig. 4. Plot of the left-hand side of Eq. (4) against the reciprocal temperature for $\mathrm{CO}$ adsorbed on $\mathrm{H}-\mathrm{FER}$; data obtained from the $\mathrm{O}-\mathrm{H}$ stretching band at $3605 \mathrm{~cm}^{-1}$

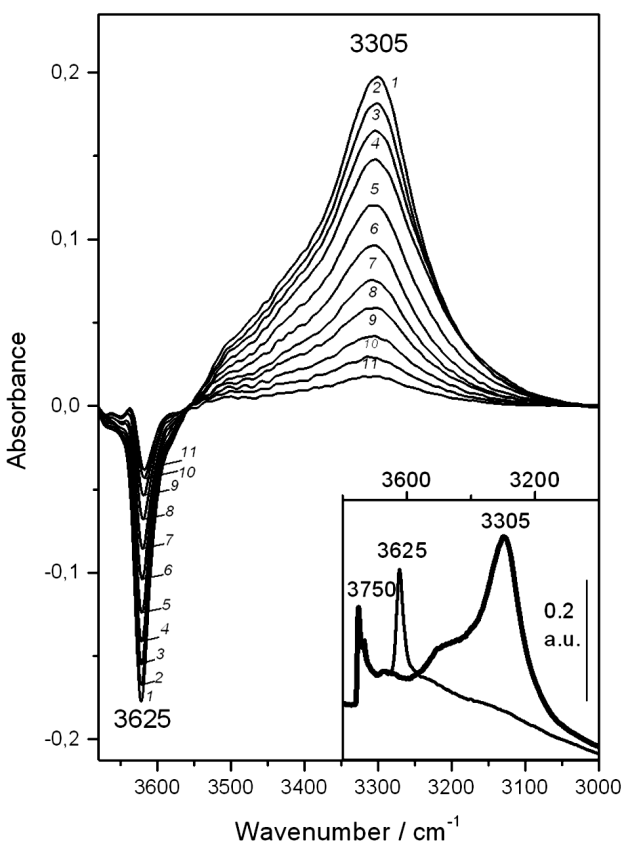

Fig. 5. As in Fig. 1; CO adsorbed on H-MCM-22. Temperature (in $\mathrm{K}$ ) and equilibrium pressure (mbar, in brackets) are as follows: $1-154$ (6.52); $2-160$ (6.99); $3-166(7.37) ; 4-$ $172(7.72) ; 5-178(8.01) ; 6-184(8.29) ; 7-190(8.55) ; 8-$ 196 (8.75); $9-202(8.93) ; 10-208(9.11) ; 11-214$ (9.24)

with a weaker silanol band at $3747 \mathrm{~cm}^{-1}$ (which is of no concern herein).

Representative IR spectra of carbon monoxide adsorbed at a variable temperature on a thin self- supported zeolite wafer are shown in Fig. 3 (main body). As expected, the interaction of zeolite with adsorbed CO left the silanol band unaltered, while the intensity of the band at $3605 \mathrm{~cm}^{-1}$ decreased to an extent depending on the temperature. Simultaneously, a new (broader) IR absorption band due to $\mathrm{OH}$... CO species developed at $3308 \mathrm{~cm}^{-1}$. After determining the integrated intensity of the whole set of bands at $3605 \mathrm{~cm}^{-1}$, the van't Hoff plot depicted in Fig. 4 was obtained. From that linear plot, the value of $\Delta H^{0}=-28.6 \mathrm{~kJ} \mathrm{~mol}^{-1}$ was derived for the standard enthalpy of the H-bond formation between adsorbed $\mathrm{CO}$ and the H-FER Brønsted acid sites. The corresponding standard entropy change resulted to be $\Delta S^{0}=-147 \mathrm{~J} \mathrm{~mol}^{-1} \mathrm{~K}^{-1}$.

\subsection{H-MCM-22: Structure-type $M W W$}

From the parent material, MCM-29P [33, 34], the protonic zeolite H-MCM-22 ( $\mathrm{Si}$ : Al ratio 24.5 : 1) was prepared as described elsewhere [28] and checked by powder X-ray diffraction, which confirmed a good crystallinity and the absence of any diffraction line not assignable to the corresponding MWW structure type. The $\mathrm{Si}$ : Al ratio was determined by X-ray fluorescence analysis.

The FT-IR spectrum of zeolite in the O-H stretching region is displayed in Fig. 5 (inset). It shows the characteristic IR absorption band of Brønstedacid hydroxyl groups at $3625 \mathrm{~cm}^{-1}$ (and the silanol band at $3750 \mathrm{~cm}^{-1}$ ). Dosing with $\mathrm{CO}$ (at $77 \mathrm{~K}$ ) was found to erode the $3625 \mathrm{~cm}^{-1}$ band and to bring about the corresponding IR absorption band of the hydrogen-bonded $\mathrm{OH}$... CO complex, which peaks at $3305 \mathrm{~cm}^{-1}$, thus showing a $\Delta \nu(\mathrm{OH})$ shift of $-320 \mathrm{~cm}^{-1}$. Representative variable-temperature IR spectra are shown in the main body of Fig. 5. After measuring the integrated intensity of the bands at $3625 \mathrm{~cm}^{-1}$ for the whole set of VTIR spectra recorded, the van't Hoff plot shown in Fig. 6 was obtained, from which the standard enthalpy of the formation of hydrogen-bonded complexes resulted to be $\Delta H^{0}=-23.5 \mathrm{~kJ} \mathrm{~mol}^{-1}$. The corresponding value of $\Delta S^{0}$ was $-130 \mathrm{~J} \mathrm{~mol}^{-1} \mathrm{~K}^{-1}$. As a further check, the interaction enthalpy of $\mathrm{CO}$ with the same $\mathrm{H}$ MCM-22 sample was also determined by adsorption calorimetry at $303 \mathrm{~K}$ (see Ref. [35] for details). Figure 7 shows the obtained plots of the differential heat of adsorption as a function of the coverage. Note that, in order to check the reproducibility, the sec- 
ond measurement run was performed after outgassing $\mathrm{CO}$ adsorbed in the first run. The average of both sets of measurements gave an adsorption heat of $21( \pm 2) \mathrm{kJ} \mathrm{mol}^{-1}$, to be compared with the value of $\Delta H^{0}=-23.5( \pm 2) \mathrm{kJ} \mathrm{mol}^{-1}$ obtained by VTIR spectroscopy; both values are approximately equal within the limits of experimental errors.

\section{Discussion and Conclusions}

The foregoing case studies demonstrate how VTIR spectroscopy can be used to quantify the Brønsted acid strength of protonic zeolites. Moreover, the case of $\mathrm{CO}$ adsorption on H-MCM-22 (Section 3.3) shows that the $\Delta H^{0}$ value obtained by VTIR spectroscopy agrees (within experimental error) with the corresponding adsorption heat determined by calorimetry. However, it should be remarked that, besides probing the interaction energy, VTIR spectroscopy shows simultaneously the nature of the gas-solid adsorption complex, which is characterized by the corresponding IR spectrum, thus providing the site-specific information that is not made available by calorimetry; unless the latter technique is coupled with IR spectroscopic measurements. The fact of being sitespecific confers a clear advantage to VTIR spectroscopy over adsorption calorimetry when dealing with zeolites containing point defects (such as, for instance, extra-framework aluminium species) that can adsorb CO [36,37]. In general terms, CO adsorption complexes formed on defective surface sites would be clearly discriminated (on account of their different spectroscopic signature) from H-bonded adsorp-

Relevant experimental data

for the CO hydrogen bonding in protonic zeolites

\begin{tabular}{|l|c|c|c|c|}
\hline \multicolumn{1}{|c|}{ Zeolite } & $\begin{array}{c}\text { Structure } \\
\text { type }\end{array}$ & $\begin{array}{c}\mathrm{Si} / \mathrm{Al} \\
\text { ratio }\end{array}$ & $\begin{array}{c}\Delta \nu_{\mathrm{OH}}{ }^{a}, \\
\mathrm{~cm}^{-1}\end{array}$ & $\begin{array}{c}\Delta H^{b}, \\
\mathrm{~kJ} \mathrm{~mol}^{-1}\end{array}$ \\
\hline H-Beta & BEA & 20 & 305 & 27 \\
H-ZSM-5 & MFI & 30 & 303 & 29 \\
H-FER & FER & 27.5 & 297 & 28.6 \\
H-Y & FAU & 5.6 & 275 & 25.6 \\
H-MCM-22 & MWW & 24.5 & 320 & 23.5 \\
H-MCM-22 & MWW & 16.4 & 317 & 21 \\
H-MCM-56 & MWW & 16 & 316 & 20 \\
\hline
\end{tabular}

a Red-shift of the Brønsted-acid OH group upon hydrogen bonding with $\mathrm{CO}$.

${ }^{b}$ Standard enthalpy change in the formation of the $\mathrm{OH} \cdots \mathrm{CO}$ complex.

ISSN 2071-0194. Ukr. J. Phys. 2018. Vol. 63, No. 6

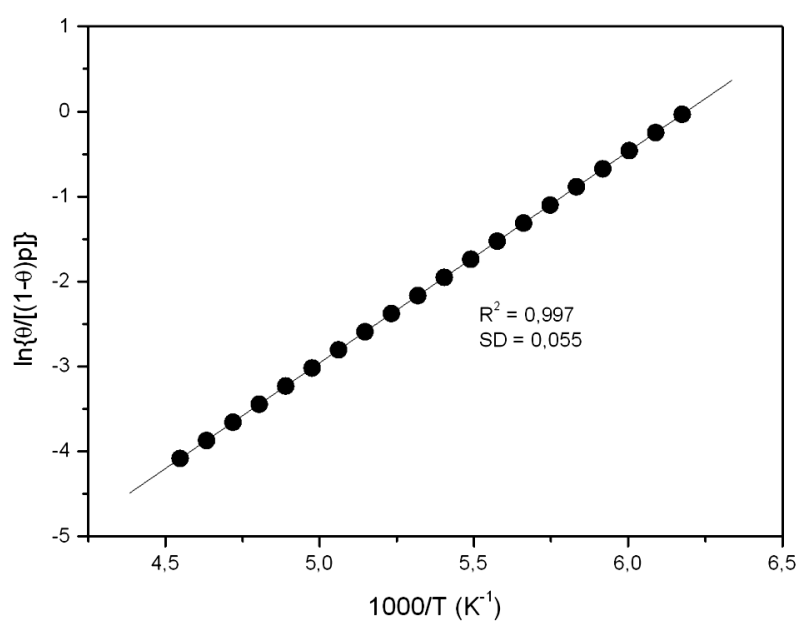

Fig. 6. Plot of the left-hand side of Eq. (4) against the reciprocal temperature for $\mathrm{CO}$ adsorbed on $\mathrm{H}-\mathrm{MCM}-22$; data obtained from the $\mathrm{O}-\mathrm{H}$ stretching band at $3625 \mathrm{~cm}^{-1}$

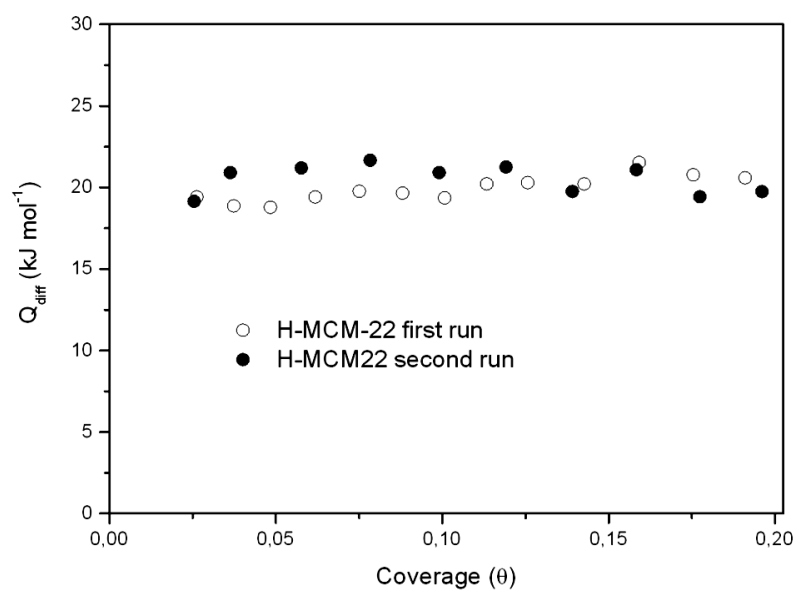

Fig. 7. Adsorption heat (as a function of the coverage) of $\mathrm{CO}$ on H-MCM-22, measured by calorimetry at $303 \mathrm{~K}$. Two independent series of measurements are shown

tion complexes when probed by VTIR spectroscopy; but that could not be the case when using adsorption calorimetry instead.

In addition to the foregoing case studies, VTIR spectroscopy has also been used to probe the interaction of $\mathrm{CO}$ with several other protonic zeolites, namely, H-Beta [27], H-Y [38], H-MCM-22 (Si/Al = $=16$ ) and H-MCM-56 [35]. The whole set of results obtained is summarized in the table, while the derived correlation between $\Delta H^{0}$ and $\Delta \nu(\mathrm{OH})$ is depicted in Fig. 8. Clearly, zeolites H-Y, H-FER and HZSM-5 do show the expected (linear) correlation be- 


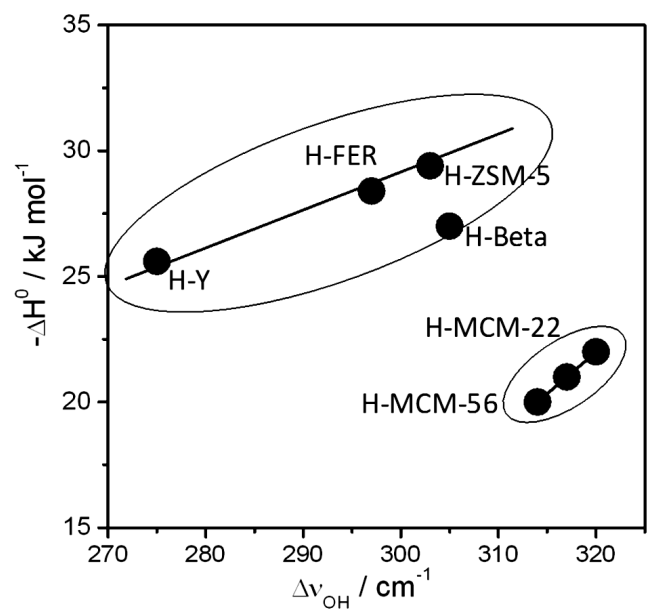

Fig. 8. Correlation between $\Delta H^{0}$ and $\Delta \nu(\mathrm{OH})$ for the $\mathrm{CO}$ hydrogen bonding in protonic zeolites

tween the corresponding (absolute) values of $\Delta \nu(\mathrm{OH})$ and $\Delta H^{0}$, but $\mathrm{H}$-Beta displays a significant deviation; and the three MWW structure-type zeolites come wide apart from the others. These findings strongly suggest that the rather common practice of ranking the Brønsted acid strength of protonic zeolites by the corresponding value of $\Delta \nu(\mathrm{OH})$, probed by IR spectroscopy (at a fixed temperature) of adsorbed carbon monoxide, should be viewed with some caution, especially when dealing with widely different structure types. To conclude, it seems pertinent to remark that, some time ago, Tsai et al. [39] and Zhou et al. [40] have found that H-MCM-22 showed a weaker Brønsted acidity than H-ZSM-5, when both zeolites were probed by the temperature programmed desorption of ammonia; and yet $\Delta \nu(\mathrm{OH})$ is significantly larger for H-MCM-22 (Table). These facts give a further support to the foregoing arguments against the undiscriminated use of $\Delta \nu(\mathrm{OH})$ to rank the Brønstedacid strength of protonic zeolites.

1. R. Szostak. Molecular Sieves: Principles of Synthesis and Identification (Van Nostrand Reinhold, 1989).

2. M.G. Clerici. Zeolites for fine chemicals production. Top. Catal. 13 (4), 373 (2000).

3. B. Xu, C. Sievers, S.B. Hong, R. Prins, J.A. van Bokhoven. Catalytic activity of Brønsted acid sites in zeolites: Intrinsic activity, rate-limiting step, and influence of the local structure of the acid sites. J. Catal. 244, 163 (2006).

4. D.P. Serrano, R.A. García, G. Vicente, M. Linares, D. Procházková, J. Čejka. Acidic and catalytic properties of hierarchical zeolites and hybrid ordered mesoporous materials assembled from MFI protozeolitic units. J. Catal. 279, 366 (2011).

5. E.T.C. Vogt, G.T. Whiting, A.D. Chowdhury, B.M. Weckhuysen. Zeolites and zeotypes for oil and gas conversion. In Advances in Catalysis. Edited by F.C. Jentoft (Academic Press, 2015), 58, p. 143.

6. K.A. Tarach, K. Gora-Marek, J. Martinez-Triguero, I. Melian-Cabrera. Acidity and accessibility studies of desilicated ZSM-5 zeolites in terms of their effectiveness as catalysts in acid-catalyzed cracking processes. Catal. Sci. Technol. 7, 858 (2017).

7. P. Losch, A.B. Pinar, M.G. Willinger, K. Soukup, S. Chavan, B. Vincent, P. Pale, B. Louis. H-ZSM-5 zeolite model crystals: Structure-diffusion-activity relationship in methanol-to-olefins catalysis. J. Catal. 345, 11 (2017).

8. J. Čejka, R.E. Morris, D.P. Serrano. Catalysis on zeolites catalysis science \& technology. Catal. Sci. Technol. 6, 2465 (2016).

9. W.E. Farneth, R.J. Gorte. Methods for characterizing zeolite acidity. Chem. Rev. 95, 615 (1995).

10. A.L. Blumenfeld, J.J. Fripiat. ${ }^{27} \mathrm{Al}^{1} \mathrm{H}$ REDOR NMR and ${ }^{27} \mathrm{Al}$ spin-echo editing: A new way to characterize Brønsted and Lewis acidity in zeolites. J. Phys. Chem. B 101, 6670 (1997).

11. C. Busco, A. Barbaglia, M. Broyer, V. Bolis, G.M. Foddanu, P. Ugliengo. Characterisation of Lewis and Brønsted acidic sites in H-MFI and H-BEA zeolites: a thermodynamic and ab initio study. Thermochim. Acta 418, 3 (2004).

12. L. Peng, Y. Liu, N. Kim, J.E. Readman, C.P. Grey. Detection of Brønsted acid sites in zeolite HY with high-field 17O-MAS-NMR techniques. Nature Mater. 4, 216 (2005).

13. J. Vaculik, M. Setnicka, R. Bulanek. Study of Brønsted acid site in H-MCM-22 zeolite by temperature-programmed desorption of ammonia. J. Therm. Anal. Calorim. 125, 1217 (2016).

14. A. Auroux. Microcalorimetry methods to study the acidity and reactivity of zeolites, pillared clays and mesoporous materials. Top. Catal. 19, 205 (2002).

15. M. Niwa, N. Katada. New method for the temperatureprogrammed desorption (TPD) of ammonia experiment for characterization of zeolite acidity: A review. Chem. Rec. 13, 432 (2013).

16. E.G. Derouane, J.C. Védrine, R. Ramos Pinto, P.M. Borges, L. Costa, M.A.N.D.A. Lemos, F. Lemos, F.R. Ribeiro. The acidity of zeolites: Concepts, measurements and relation to catalysis: A review on experimental and theoretical methods for the study of zeolite acidity. Catal. Rev. Sci. Eng. 55, 454 (2013).

17. A. Zecchina, C. Otero Areán. Diatomic molecular probes for mid-IR studies of zeolites. Chem. Soc. Rev. 25, 187 (1996).

18. E. Garrone, B. Fubini, B. Bonelli, B. Onida, C.O. Areán. Thermodynamics of CO adsorption on the zeolite Na-ZSM5 A combined microcalorimetric and FTIR spectroscopic study. Phys. Chem. Chem. Phys. 1, 513 (1999).

ISSN 2071-0194. Ukr. J. Phys. 2018. Vol. 63, No. 6 
19. K. Hadjiivanov. Identification and characterization of surface hydroxyl groups by infrared spectroscopy. Adv. Catal. 57, 99 (2014)

20. W. Daniell, N.Y. Topsoe, H. Knozinger. An FTIR study of the surface acidity of USY zeolites: Comparison of CO, $\mathrm{CD}_{3} \mathrm{CN}$, and $\mathrm{C}_{5} \mathrm{H}_{5} \mathrm{~N}$ probe molecules. Langmuir 17, 6233 (2001).

21. C. Lamberti, A. Zecchina, E. Groppo, S. Bordiga. Probing the surfaces of heterogeneous catalysts by in situ IR spectroscopy. Chem. Soc. Rev. 39, 4951 (2010).

22. C.O. Areán. Dinitrogen and carbon monoxide hydrogen bonding in protonic zeolites: Studies from variabletemperature infrared spectroscopy. J. Mol. Struct. 880, 31 (2008).

23. A. Pulido, M.R. Delgado, O. Bludský, M. Rubeš, P. Nachtigall, C.O. Areán. Combined DFT/CC and IR spectroscopic studies on carbon dioxide adsorption on the zeolite H-FER. Energy Environ. Sci. 2, 1187 (2009).

24. M. Mihaylov, S. Andonova, K. Chakarova, A. Vimont, E. Ivanova, N. Drenchev, K. Hadjiivanov. An advanced approach for measuring acidity of hydroxyls in confined space: a FTIR study of low-temperature CO and ${ }^{15} \mathrm{~N}_{2}$ adsorption on MOF samples from the MIL-53(Al) series. Phys. Chem. Chem. Phys. 17, 24304 (2015).

25. J.A. Lercher, C. Grundling, G. Eder-Mirth. Infrared studies of the surface acidity of oxides and zeolites using adsorbed probe molecules. Catal. Today 27, 353 (1996).

26. V. Van Speybroeck, K. Hemelsoet, L. Joos, M. Waroquier, R.G. Bell, C.R.A. Catlow. Advances in theory and their application within the field of zeolite chemistry. Chem. Soc. Rev. 44, 7044 (2015).

27. M.R. Delgado, C. Otero Areán. Carbon monoxide, dinitrogen and carbon dioxide adsorption on zeolite H-Beta: IR spectroscopic and thermodynamic studies. Energy 36, 5286 (2011).

28. M.R. Delgado, R. Bulánek, P. Chlubná, C. Otero Areán. Brønsted acidity of H-MCM-22 as probed by variabletemperature infrared spectroscopy of adsorbed $\mathrm{CO}$ and $\mathrm{N}_{2}$. Catal. Today 227, 45 (2014).

29. C.O. Areán, G. Turnes Palomino, A. Zecchina, G. Spoto, S. Bordiga, P. Roy. Cation-carbon stretching vibration of adducts formed upon $\mathrm{CO}$ adsorption on alkaline zeolites. Phys. Chem. Chem. Phys. 1, 4139 (1999).

30. E. Garrone, C.O. Areán. Variable temperature infrared spectroscopy: A convenient tool for studying the thermodynamics of weak solid-gas interactions. Chem. Soc. Rev. 34, 846 (2005).

31. A.A. Tsyganenko, P.Yu. Storozhev, C.O. Areán. IRspectroscopic study of the binding isomerism of adsorbed molecules. Kinet. Catal. 45, 530 (2004).

32. P. Nachtigall, O. Bludský, L. Grajciar, D. Nachtigallová, M.R. Delgado, C.O. Areán. Computational and FTIR spectroscopic studies on carbon monoxide and dinitrogen adsorption on a high-silica H-FER zeolite. Phys. Chem. Chem. Phys. 11, 791 (2009).

33. W.J. Roth, J. Čejka. Two-dimensional zeolites: Dream or reality? Catal. Sci. Technol. 1, 43 (2011).
34. W.J. Roth, P. Chlubná, M. Kubu, D. Vitvarová. Swelling of MCM-56 and MCM-22P with a new medium - surfactant-tetramethylammonium hydroxide mixtures. Catal. Today 204, 8 (2013).

35. C.O. Areán, M.R. Delgado, P. Nachtigall, H.V. Thang, M. Rubeš, R. Bulánek, P. Chlubná-Eliašová. Measuring the Brønsted acid strength of zeolites - does it correlate with the $\mathrm{O}-\mathrm{H}$ frequency shift probed by a weak base? Phys. Chem. Chem. Phys. 16, 10129 (2014).

36. A. Zecchina, S. Bordiga, G. Spoto, D. Scarano, G. Petrini, G. Leofanti, M. Padovan, C.O. Areán. Low-temperature Fourier-transform infrared investigation of the interaction of CO with nanosized ZSM5 and silicalite. J. Chem. Soc. Faraday Trans. 88, 2959 (1992).

37. V. Dondur, V. Rakic, L. Damjanovic, A. Auroux. Comparative study of the active sites in zeolites by different probe molecules. J. Serb. Chem. Soc. 70, 457 (2005).

38. C.O. Areán, O.V. Manoilova, A.A. Tsyganenko, G.T. Palomino, M.P. Mentruit, F. Geobaldo, E. Garrone. Thermodynamics of Hydrogen bonding between $\mathrm{CO}$ and the supercage Brønsted acid sites of the $\mathrm{H}-\mathrm{Y}$ zeolite - studies from variable temperature IR spectrometry. Eur. J. Inorg. Chem. 1739 (2001).

39. C.C. Tsai, C.Y. Zhong, L. Wang, S.B. Liu, W. Chen, T.C. Tsai. Vapor phase Beckmann rearrangement of cyclohexanone oxime over MCM-22. Appl. Catal. A 267, 87 (2004).

40. Z. Zhu, Q. Chen, Z. Xie, W. Yang, C. Li. The roles of acidity and structure of zeolite for catalyzing toluene alkylation with methanol to xylene. Micropor. Mesopor. Mater. 88, 16 (2006).

Received 10.01.18

К.О.Ареан

\section{ВИЗНАЧЕННЯ КИСЛОТНОСТ}

БРОНСТЕДА ДЛЯ ПРОТОНОВАНИХ ЦЕОЛІТІВ ІЧ-СПЕКТРОСКОПІЕЮ ЗА ЗМІННОЇ ТЕМПЕРАТУРИ

Р е $з$ ю м е

Багато застосувань цеолітів у промисловості як кислотних каталізаторів у твердій фазі грунтуються на їх високій кислотності Бронстеда, що визначає їх каталітичні властивості і селективність і на наявності точної апаратури для вимірювання кислотності. Зміна ентальпії $\Delta H^{0}$, що супутня взаємодії за допомогою водневого зв'язку між слабкою основою (такою як окис вуглецю) і гідроксильною групою в $[\mathrm{Si}(\mathrm{OH}) \mathrm{Al}]$ з кислотністю Бронстеда, має безпосередньо корелювати з кислотністю цеолітів. Для простоти замість $\Delta H^{0}$ зазвичай вимірюється при низькій (фіксованій) температурі з застосуванням ІЧ-спектроскопії батохромний зсув частоти коливань $\mathrm{OH}, \Delta \nu(\mathrm{OH})$, що корелює з силою кислоти для різних кислотностей цеолітів. У даній роботі ІЧ-спектроскопію за змінної температури застосовано для одночасного визначення $\Delta H^{0}$ i $\Delta \nu(\mathrm{OH})$ та дано огляд результатів недавніх експериментів. Показано, що практика визначення сили кислоти по зрушенню частоти О-Н коливань при взаємодії зі слабкою основою може бути помилковою, особливо при порівнянні цеолітів з широким діапазоном структур. 